Journal of Fisheries International 5 (2): 36-43, 2010

ISSN: $1817-3381$

(C) Medwell Journals, 2010

\title{
Aspects of Reproductive Biology in Mudskipper, Periophthalmus papilio from Mangrove Swamps of Lagos Lagoon, Lagos, Nigeria
}

\author{
Emmanuel O. Lawson \\ Department of Fisheries, Faculty of Science, Lagos State University, \\ Ojo P.O. Box 001, LASU Post Office, Lagos, Nigeria
}

\begin{abstract}
The present study was conducted on aspects of reproductive biology of mudskipper, Periophthalmus papilio (Bloch and Schneider 1801) in the mangrove swamps of Lagos lagoon in Nigeria. $P$. papilio is an economically valued fish species both as food for the populace and baits for industrial or offshore fisheries. About 2167 individuals were caught from the lagoon with non return valve traps between May 2006 and May 2008. Data on sex, Total Length (TL), gonad (gW) and body Weight (bW) measurements were carried out on individual specimen. These data were used in the determination of sex ratio, Gonadosomatic Index (GSI) and maturation in this species. The sex ratio of 1 male to 1.42 females was observed but not statistically different but a departure from the theoretical 1 male: 1 female sex ratio. The females were significantly more than the males. The eggs were as small as $0.20 \mathrm{~mm}$ and as big as $0.50 \mathrm{~mm}$ (mean $=0.36 \pm 0.01 \mathrm{~mm}$ for average fish of $116 \mathrm{TL}$ ). The GSI values varied from $0.01-0.48 \%$ in males and between 0.11 and $8.40 \%$ in females. Seven stages of maturity: immature, immature and developing, ripening, ripe, ripe running, spent and resting and recovering were encountered. Male fish matured at $70 \mathrm{~mm}$ TL and females at $60 \mathrm{~mm}$ TL. However, both sexes were at the ripe stage at $90 \mathrm{~mm}$ TL. In conclusion, females were significantly more than the males. Between 0.01 (in males) and $8.40 \%$ in (females) of the body mass was useful in gonad development. The maturity of females was earlier than the males. The maturity stages obtained from the present study were in conformity with those reported in other teleosts. Therefore, the sex ratios, egg diameters, gonadosomatic index and maturation of the species in Lagos lagoon were investigated to provide baseline data for future ecological and biological studies of this species and other species within the estauaries and coastal waters.
\end{abstract}

Key words: Atretic, fecundity, gonadosomatic index, oocyte, spermatocyte, Nigeria

\section{INTRODUCTION}

The gobies including the mudskipper, Periophthalmus papilio is made up of a large number of species. They are bony and highly active fishes and their versatility is reflected in their eurylaline and amphibious nature. $P$. papilio belongs to the family Periophthalmidae but formally of family Gobiidae. It is the only species found in the Gulf of Guinea including West African coast, estuaries and lagoons (Irvine, 1947; FAO, 1990) it lives in the shallow and exposed inter tidal mudflats of estuaries mangrove swamps and it is amphibious (FAO, 1990). Other related species found in other parts of the world include P. chrysospilos in Singapore (Ip et al., 1990) and $P$. koelreuteri in East Africa. Boleophthalmus boddaerti and B. woberi are found inhabiting estuary of Pasir Ris in Singapore. Periophthalmus was grouped into indigenous or permanent element of the brackish waters of estuaries and lagoons (Lawson, 2004a). Aspects of the biology, ecology and early life history of mudskippers have attracted attentions of several researchers (Murdy, 1989;
Etim et al., 2002; Jaafar and Larson, 2008; Khaironizam and Norma-Rashid, 2002; Udo, 2002; Lawson 2004a, b; Swanson and Alice, 2004; Sarimin et al., 2009). A new species, Periophthalmus takita was recently discovered in Australia (Jaafar et al., 2006).

Study area-Lagos lagoon: Lagos lagoon (Fig. 1), Nigeria is located on longitude $3^{\circ} 20^{\prime}$ and $3^{\circ} 50^{\prime} \mathrm{W}$ and latitude between $6^{\circ} 24^{\prime}$ and $6^{\circ} 36^{\prime} \mathrm{N}$. It is the largest of lagoon systems in West African coast covering $208 \mathrm{~km}^{2}$. It is an open tidal estuary. The lagoon is fed in the north by Ogun river which is the major source of water to the lagoon; the southern margin is bounded by 5 cowries creeks. The Badagry creek is the main waterway leading to Badagry and Nigeria/Benin Republic border. Connected with 5 cowries creek is kuramo water which is a channel which runs through the mangrove swamps. The lagoon opens into the Atlantic Ocean via the Lagos habour. The adjacent Lekki and Epe lagoons bounded it in the east. Previously, several studies were conducted on benthic, fishes and fisheries of this water body (Olaniyan, 1957; 


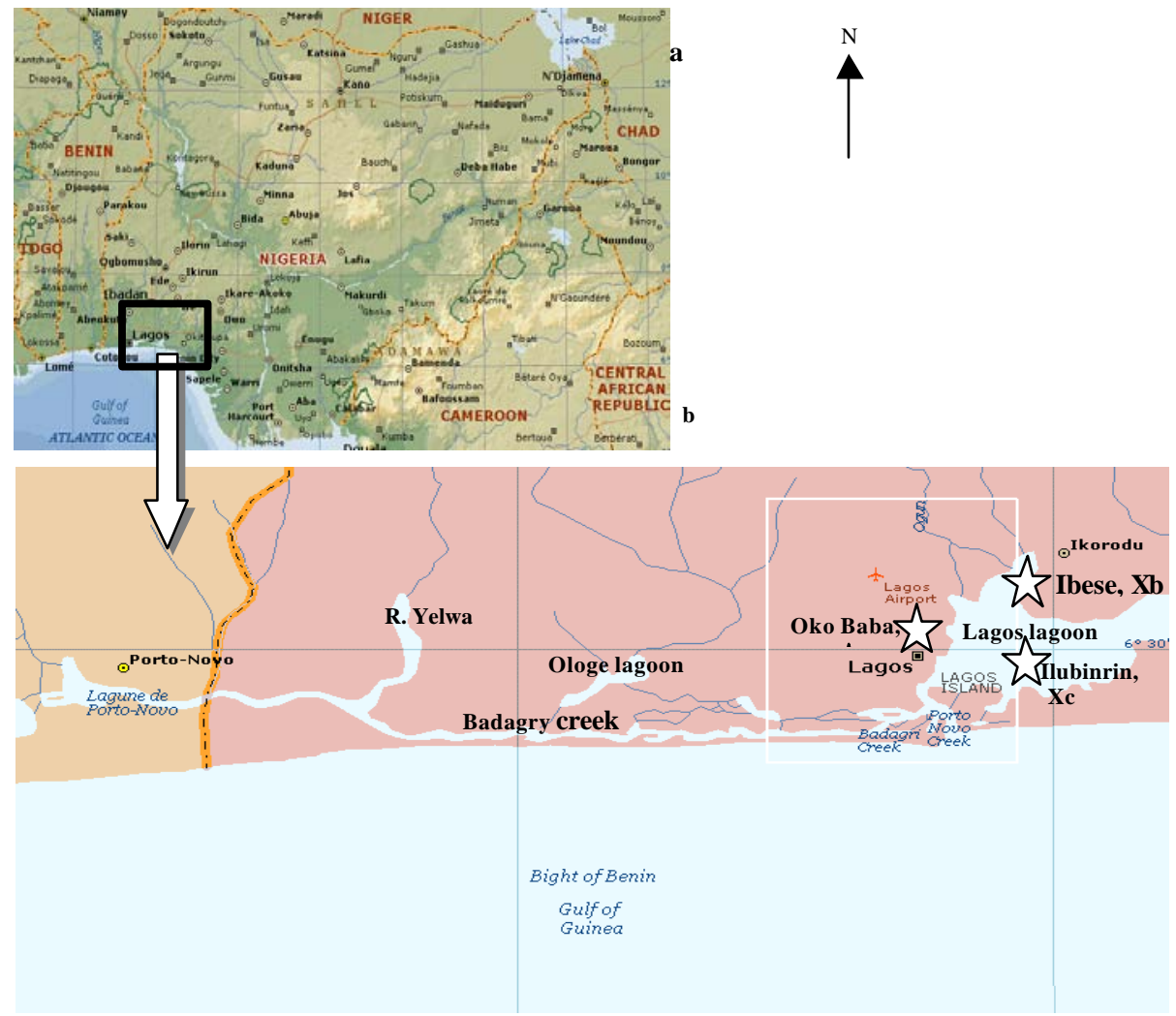

Fig. 1: (a) The adaministrative map of Nigeria (b) Inset Lagos lagoon showing the sampling stations ( $\mathrm{Xa}, \mathrm{Xb}$ and $\mathrm{Xc}$ )

Oyenekan, 1972; Fagade and Olaniyan, 1972, 1973; Yoloye, 1976; Kusemiju et al., 1983; Ajao, 1990; Brown, 1991; Lawson, 1991, 1998).

\section{MATERIALS AND METHODS}

Collection of specimens: About 2,167 specimens of mudskipper, Periophthalmus papilio were caught from mudflats of the mangrove swamps of Lagos lagoon between May, 2006 and May, 2008 with non-return valve traps. Services of local fishermen were employed in setting up traps and diurnal collections of the fish. Specimens were preserved in $4 \%$ formaldehyde prior laboratory procedures.

Laboratory procedures and data collection: Biometric data on Total Length (TL) to the nearest $1 \mathrm{~mm}$ and body weight measurements (bW) to the nearest $0.01 \mathrm{~g}$ were recorded. Further laboratory analysis was carried out by opening bellies of the specimens to ascertain sex and gonad weight $(\mathrm{gW})$.

The maturity stages were determined by naked eye and microscopic examinations of the gonads. Methods of classifications of gonadal stages followed those of Jone (1974), Blay and Eyeson (1982), Marcus (1982) and Ugwumba (1984). Sex ratio was determined by counting numbers of male and female specimens. The ratios were tested with Chi-squared analyses $\left(\chi^{2}\right)$. The annual gonadal cycle was determined from the changes in gonad weight as indicated by the Gonadosomatic Index (GSI). This was estimated from the relationship:

$$
\mathrm{GSI}=\mathrm{gW} \cdot 100 \cdot \mathrm{bW}^{-1}
$$

The relationship between $\mathrm{gW}$ and $\mathrm{bW}$ of the fish was obtained from equation: $\mathrm{gW}=\mathrm{a}+\mathrm{b}$. bW. Where $\mathrm{y}=$ gonadosomatic index, $\mathrm{x}, \mathrm{w}=$ body weight $(\mathrm{g})$. Parameters $\mathrm{a}$ and $\mathrm{b}$ were estimated from the least squares regression method. Egg size or oocyte diameter (od) was measured with a graduated micrometer that was mounted in the eyepiece of a binocular microscope. The regression coefficient, $\mathrm{r}$ was calculated to the nearest $0.01 \mathrm{~mm}$. The relationship that existed between and fish TL was determined.

\section{RESULTS AND DISCUSSION}

Sex ratio: A total of 2167 specimens of $P$. papilio were collected from the mangrove swamps of Lagos lagoon. This number comprised 281 immature, 779 male and 1107 female individuals giving a sex ratio of 1 male: 1.42 females. A Chi-square $\left(\chi^{2}\right)$ revealed a significant departure 
from 1 male: 1 female sex ration $\left(\chi^{2}=57.04>\chi_{1,0.05}^{2}=3.84\right)$, indicating females were significantly more than males.

Gonadosomatic index: The values of GSI in this study are shown in Table 1. In males it ranged between 0.01 and $0.48 \%(0.104 \pm 0.004 \%)$ and in females from $0.11-8.40 \%$. $(2.69 \pm 0.003 \%)$. The gonad weight-total length relationships in both sexes of $P$. papilio in Lagos lagoon (Fig. 2 and 3). For males:

$$
\mathrm{gW}=-0.0434+0.0005 \mathrm{TL}(\mathrm{n}=126, \mathrm{r}=0.4385)
$$

For females:

$$
\mathrm{gW}=-0.7502+0.0106 \mathrm{TL}(\mathrm{n}=199, \mathrm{r}=0.3835)
$$

Egg diameter: In this study, 4 different groups of egg sizes were observed in the lagoon viz: $0.2,0.25,0.33$ and $0.50 \mathrm{~mm}$ in diameters representing $15.56,12.06,45.73$ and $26.63 \%$, respectively (Fig. 4). The mean egg diameter was $0.36 \pm 0.002 \mathrm{~mm}$. The relationship between oocyte diameter (od) and fish Total Length (TL) is shown in Fig. 5 as: od $=0.1685+0.0014$ TL $(n=199, r=0.2154)$.

Stages of maturity: Seven maturity stages were encountered in the study. Both microscopic and macroscopic descriptions of the maturity stages for the males and females in this study are shown in Table 2.

Size at maturity: Length frequency histograms of fish at different stages of maturity are shown in Fig. 5. Stage II specimens measured between 70 and $150 \mathrm{~mm}$ TL for males and females, respectively. The modal length frequency of $100 \mathrm{~mm}$ TL was by 26.52 of males and $30.44 \%$ of females (Fig. 6).

Stage III specimens were 80-160 for males and 90-190 mm TL for females (the modal length was $120 \mathrm{~mm}$ ). However, 25.0 and $23.01 \%$ of males and females, respectively made up the modal length. Stage IV fish measured between 90 and $180 \mathrm{~mm} \mathrm{TL}$ (for males) and 90-160 mm TL (for females), the modal lengths were 140 and $120 \mathrm{~mm}$ TL, respectively. The cohorts were 17.53 and $23.53 \%$ males and females, respectively. Stage V specimens occurred between 90 and $160 \mathrm{mmTL}$ (males) and from 100-180 mmTL (females). At $120 \mathrm{~mm}$ TL, most females were already at ripe (IV) and ripe running (VI) stages earlier than males (140 mmTL). The fish in stage VI ranged from 100-160 $\mathrm{mm}$ TL. The percentages length frequencies for the cohorts were 26.53 and $24.62 \%$, respectively for males at $150 \mathrm{~mm} \mathrm{TL}$ and females at 130 $\mathrm{mm}$ TL. At Stage VII, $60 \%$ of the specimens were $130 \mathrm{~mm}$ TL. The females were between 110 and $160 \mathrm{~mm}$ TL, $28.57 \%$ of them measured $120 \mathrm{~mm}$ TL. At $90 \mathrm{~mm}$ TL both sexes

\begin{tabular}{|c|c|c|c|}
\hline \multirow[b]{2}{*}{ Sex } & \multicolumn{3}{|c|}{ Range (\%) } \\
\hline & Min & Max & Mean \pm S.E $(\%)$ \\
\hline Males & 0.01 & 0.48 & $0.104 \pm 0.004$ \\
\hline Females & 0.11 & 8.40 & $2.69 \pm 0.03$ \\
\hline
\end{tabular}
attained their ripe stage.

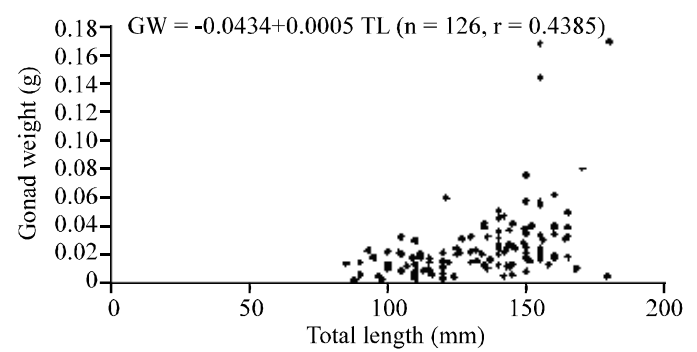

Fig. 2: Gonad weight-total length relationship in male $P$. papilio from mangrove swamps of Lagos lagoon, Nigeria

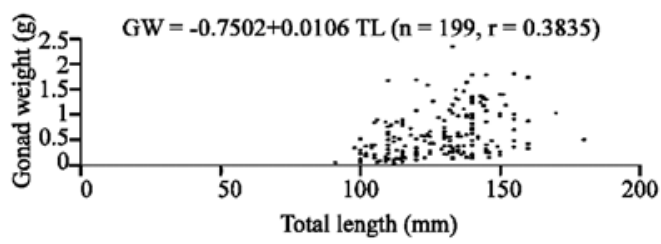

Fig. 3: Gonad weight-total length relationship in female P. Papilio from mangrove swamps of Lagos lagoon, Nigeria

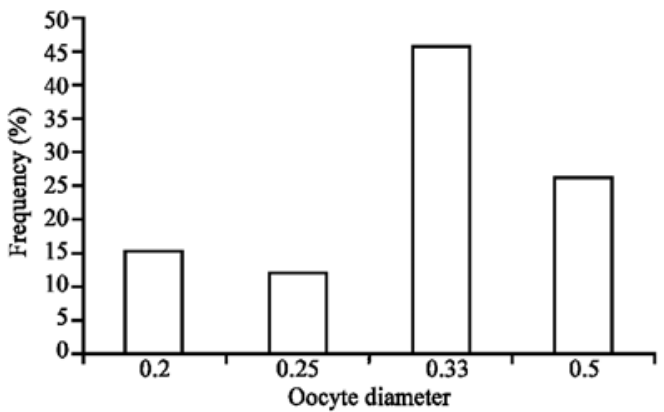

Fig. 4: Percentage frequency distribution of Oocyte diameter in $P$. papilio in Lagos lagoon, Nigeria

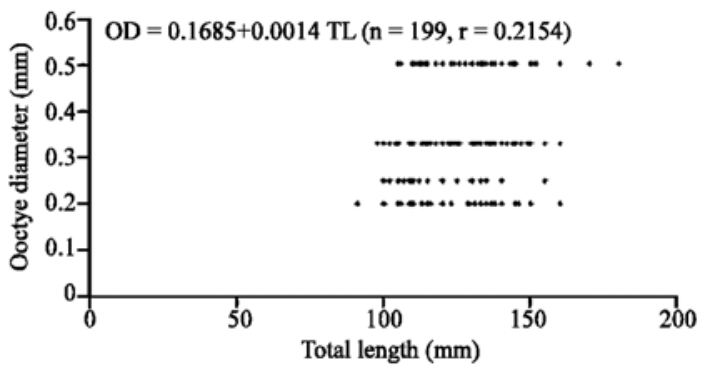

Fig. 5: Relationship between Oocyte diameter and fish total length of $P$. papilio in Lagos lagoon, Nigeria 
Table 2: Summary of different stages of maturity of $P$. papilio from mangrove of Lagos lagoon, Lagos, Nigeria

\begin{tabular}{lll}
$\begin{array}{l}\text { Maturity } \\
\text { stages }\end{array}$ & Males & Females \\
\hline $\begin{array}{l}\text { Stage I } \\
\text { presence } \\
\text { (Immature) }\end{array}$ & $\begin{array}{l}\text { The abdominal cavity. Macroscopic examination did not reveal } \\
\text { presence of accessory sexual organs which were associated with } \\
\text { males. The microscopic examination showed no sex differentiation. } \\
\text { The cells associated with the gonads were rudimentarily developed } \\
\text { and could not be differentiated. Hence, thespecimens were } \\
\text { classified as immature }\end{array}$ & $\begin{array}{l}\text { The abdominal cavity. Macroscopic examination did not reveal } \\
\text { of accessory sexual organs which were associated with females. The } \\
\text { microscopic examination showed no sex differentiation. The cells } \\
\text { associated with the gonads were rudimentarily developed and could } \\
\text { not be differentiated. Hence, the specimens were classified as immature }\end{array}$ \\
\end{tabular}

Stage II Macroscopically, the testes were flattened and 1-2mm broad whitish (Immature and lobed. They occupied $1 \%$ of the body cavity and the accessory and sexual organs were visible. Testicular wall was thick with primary Developing) spermatocyte predominating periotoneum. The mesothelium of the Developing) spermatocyte predominating periotoneum. The mesothelium of the peritoneum was very thick. The stoma and interlobular septa were very conspicuous

Stage III In early stage (phase 1) of ripening, the testes became fatter, off white (Ripening) and occupied 1/8th of the abdominal cavity. Blood vessels were visible through testis wall. Gonad length: width ratio was 2.8 . Primary spermatocytes and spermatids were pronounced. In the late stage (Phase 2) of the ripening, the testes became firm and whiter and occupied $1 / 5$ th of the abdominal cavity. Lobulation of the right and left testes started. The length: width ratio was 2.4 . The accessory sexual organs were of equal length with the testes. The secondary spermatozoa were present. The septa were not fully organized

Stage IV The testes were fully swollen and multilobed at this stage but did not (Ripe) occupy more than $1 / 4$ th of the body cavity. The colour was creamy white. The accessory sexual organs grew past the testes. The secondary and tertiary spermatocytes were dominant while few primary spermatocytes were represented. The testicular wall was $30 \mu \mathrm{m}$. The testicular septa were well organized and distinct

Stage V

(Ripe

The testes were broadest, mostly firm but some were flaccid and running) highly lobulated. They were completely white but the posterior tip sometimes grew with speckled appearance. The accessory sexual organs were fully developed and became longer than the testes. No blood vessels and thick milt exuded on slight pressure before preservation.Testis length: width ratio was 2.2 and it extended for $50 \%$ of the abdominal cavity The lumen contained spermatozoa. The empty spaces in the lumen also contained spermatocytes and spermatozoa. Most of the spermatozoa migrated towards the periphery of the lobule and the more advanced stages such as primary and secondary spermatocytesand the spermatids were found towards the interior. The testicular wall reached $30 \mu \mathrm{m}$

Stage VI The testes reduced in size and sometimes very small, flaccid and walls (Spent) were hard in texture. They were dark brown colour and no blood vessel visible. Milts were absent, testis length: width ratio was 3.2 and gonad extended for $30 \%$ of the abdominal cavity. Wall reached $40 \mu \mathrm{m}$. The accessory sexual organs well developed and longer than what in stage $\mathrm{V}$. The septa disappeared and mesothelium was thickest
Extemal or macroscopic appearance of the ovaries showed that they were small and rounded with a rough surface and soft texture. They were creamy in colour and measured between $1 / 8$ th $(12.5 \%)$ and $1 / 4$ th (25.0\%) of the length of the abdominal cavity. They were translucent with blood vessels forming internally; none of the oocytes were visible through the ovary wall.Histological appearance was characterized by the presence of many oocytes very conspicuous $(0.025-0.05 \mathrm{~mm})$. The larger oocytes had cytocplasm vacuoles. The ovary wall was thick at $50 \mu \mathrm{m}$ and folded. The oocytes were irregularly shaped but few were rounded

The ovaries were swollen and lobed when observed macroscopically. A heavy network of vessels appeared extemally on the surface of the ovary wall. Yellowish oocytes were visible to naked eye through the ovary wall. The gonad extended for about $60-70 \%$ of the abdominal cavity.The histological observation of the ovaries at this stage showed that many oocytes of between 0.1 and $0.2 \mathrm{~mm}$ were shown. Larger oocytes with cytoplasmic vacuoles were very few and had small yolk droplets. The primary and secondary vitellogenic oocytes dominated while tertiary vitelogenic oocytes were represented in the gonad. The cytoplasm of larger oocytes was filled with densely staining yolk granules. The ovarian wall was $70 \mu \mathrm{m}$ thick

Exernal appearance showed that the ovaries at this stage were almost filling the body cavity occupying $80-90 \%$ of abdominal cavity. The shedding of eggs has not commenced and otherwise soft. The eggs were rounded with a rough granular surface given a hollow sac like appearance. Blood vessels coalesced to form larger ones on the extema 1 surface of the ovary wall. Yellowish colour was possible due to the large yellow oocytes that were visible through ovary wall. The histological observation of the gonads showed that the secondary and tertiary vitellogenic oocytes dominated the gonad with very few primary oocytes. The theca externa were prominent. The hyaline oocytes were present but usually collapsed by histological processing. Ovarywall was $90 \mu \mathrm{m}$ thick; many oocytes were between $0.2-0.5 \mathrm{~mm}$ indiameter but usually $0.35 \mathrm{~mm}$ in size. Many oocytes were at stages II and III. There were blood vessels internally but some of the yolky oocytes were atretic

The oocytes or eggs flowed from the vent on slight pressure and the ovary occupied $99 \%$ of the abdominal cavity and rendered alimentary canal and gut almost inconspicuous

Oocytes looked exactly like those in the ripe stage and were laid singly with space (septa) in between as shown in most of the oocytes were in their tertiary vitellogenic stage

The ovaries were reduced in size, flaccid but ovary wall was touch and smooth with no granulation. The colour was dark red. The residual oocytes were present and visible through flabby wall. The ovary length: width ratio was 4.5 and gonad extended for $50 \%$ of the abdominal cavity. The diameters of the oocytes were very few and had a thin densely staining cytoplasm. A few atretic residual oocytes were present and invasion of oocytes by follicular cells was noted. There was a 
Table 2: Continue Maturity stages Males atresia. The septum was disorganized and there was no empty follicular coat. The ovary wall was $300 \mu \mathrm{m}$ thick. The lumen of the ovary contained much debris that was residual cells

Stage VII (Resting and recovering)
Dark patches visible through the testis wall. The testes were about a third of length of body cavity or less and firmer than what obtained at spent stage and $3 \mathrm{~mm}$ broad. A big cavity was seen at the center of the gonad spermatozoa were present at the lumen. The mesothelium of theand residual peritoneum thickened
Externally, ovaries were firmer than spent stage but mainly red in colour. It occupied $60 \%$ of the body cavity and none of the residual oocytes oocytes were visible through the ovary wall sometime present The residual atretic oocytes were present when observed microscopically but the septum was not very organized. Reorganization of ovigerous lamellae started. A few reabsorbing oocytes were sometimes present
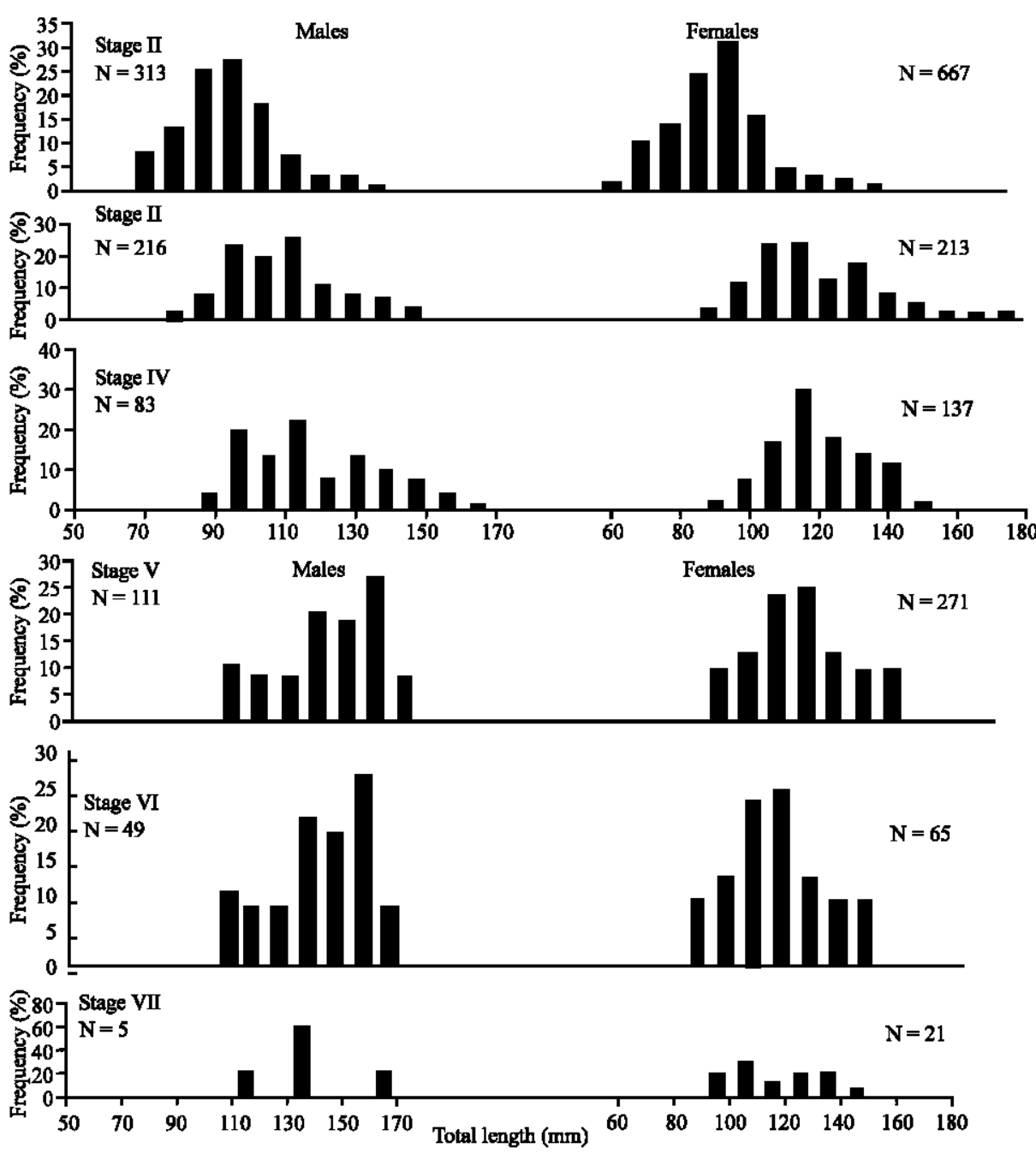

Fig. 6: Lenght frequency distribution of $P$. papilio at differnet maturity stages (II-VII) in the mangrove swamps of Lagos lagoon, Nigeria

In the present study, on the fish Periophthalmus papilio, sex ratio, gonadosomatic index, egg diameter and stages of maturity were discussed in order to clarify some characteristics of its reproductive biology. The sex ratio of this species in the mangrove swamps of Lagos lagoon indicated that females were significantly more than the males giving a sex ratio of 1 male: 1.42 females. This is a departure from theoretical 1 male to 1 female sex ratio. Higher percentages of male to female ratio in favour of the former during the spawning period was reported in non related species like Elop lacerta (Ugwumba, 1984; Lawson and Aguda, 2010) and Chrysichthys walkeri 
(Kusemiju, 1976) and while ratios in the favour of latter were reported in Ethmalosa fimbriata (Fagade and Olaniyan, 1972; Blay and Eyeson, 1982) and Mugil cephalus (Lawson, 1991) in some West African lagoons. The diameters of eggs in $P$. papilio ranged between 0.2 and $0.50 \mathrm{~mm}$ (mean $=0.36 \pm 0.002 \mathrm{~mm}$ ). The most prominent was $0.30 \mathrm{~mm}$ and the least was $0.25 \mathrm{~mm}$ egg diameters. This was in supports of the reports by Jone (1974) on Scophthalmus maximum and Marcus (1982) on Ilisha africana. The egg size in teleosts varies with the size of female (Thorpe et al., 1984) with food supply (Bagenal, 1969) and from species to species (Bagenal, 1969; Hay and Brett, 1988).

The gonadosomatic index of the fish varied between 0.01 and 0.48 in males and from $0.11-8.40 \%$ in females. Females showed higher GSI values. The GSI had been used to describe the development of gonads in Pike, Esox lucius (Danilenko, 1983). This was indication that $<0.48$ in males and $8.40 \%$ of female body weights were committed to gonad development by this species. GSI increases progressively with increased percentage of the ripe individuals towards the spawning seasons (Mohamed, 2010). The most common practice for determination of determination of a species spawning season is the establishment of of its GSI and the histological examination of the gonads (El-Greisy, 2000; Assem, 2000, 2003; Honji et al., 2006).

In this study, seven stages of gonad development were observed. These stages represented the prespawning (immature, immature and developing, ripening); spawning (ripe and ripe running) and post-spawning (spent and recovering) periods of the fish in Lagos lagoon. These stages were in conformity with that of most teleosts (Assem, 2002, 2003) although with slight modification in this study. The presence of spermatocytes and oocytes at different stages of development indicate that this species belongs to the fish with prolonged and fractional spawning season. Therefore, the fish may spawn more than once during the spawning season. This was in agreement with reports of Salem et al. (1994) on Mugil seheli, El-Greisy (2000) on Diplodus sarus, Honji et al. (2006) on Merluccius hubbsi, Garcia-Diaz et al. (2006) on blacktail comber, Serranus atricauda and Mohamed (2010) on Merluccius merluccius. Maturation process in $P$. papilio was similar to that of its relative, Boleophthalmus pectinirostris in Midori river, Japan.

Thus, maturation proceeds in this species as follows: in females, a portion of the oocytes in immature ovaries develop to the secondary yolk stage and form an oocyte group. Then parts of this oocyte develop further in turn to be spawned, leaving the remainder of the oocyte group at the secondary yolk stage. At repetition of this process, spawning comes to an end with the declination of oocyte development in the ovary. In males, the spermatids develop to primary spermatocytes which further divide to secondary spermatocytes which to be spawned as spermatozoa. Like in females, repetition process makes spawning to come to an end with declination of milt development in the testis.

\section{CONCLUSION}

The present study on mudskippers, $P$. papilio in Lagos lagoon, Nigeria showed a record of higher number of females than males (sex ratio of 1 male: 1.42 females). This was significantly different and a departure from the theoretical 1 male: 1 female ratio. The smallest eggs measured 0.20 in diameter while the biggest were $0.50 \mathrm{~mm}$ (mean $=0.36 \pm 0.002 \mathrm{~mm}$ ).

Seven stages of maturity representing the pre-spawning and post spawning stages of the fish were observed. At $90 \mathrm{~mm}$ TL both sexes attained ripe stage, spent between 100-160 mm TL. Therefore, data from this research will be useful as baseline data for carrying out further ecological and biological studies for proper management and conservation of fisheries resources of Lagos lagoon.

\section{ACKNOWLEDGEMENTS}

The researcher acknowledges both Departments of Fisheries of Lagos State University and University of Lagos, Nigeria for the use of their laboratories for this study.

\section{REFERENCES}

Ajao, E.A., 1990. The influence of domestic and industrial effluents on populations of sessile and benthic organisms in Lagos lagoon. Ph.D. Thesis, University of Ibadan.

Assem, S.S., 2000. The reproductive biology and histological characteristics of pelagic Carangid female Caranx crysos, from the Egyptian Mediterranean sea. J. Egypt. Ger. Scc. Zool., 31: 195-215.

Assem, S.S., 2003. The reproductive biology and histological and ultrastructural characteristics of the ovary female pelagic fish Pagellus erythrinus from the Egyptian Mediterranean water. J. Egypt. Ger. Scc. Zool., 42: 77-103.

Bagenal, T.B., 1969. The relationship between food supply and fecundity in brown trout, Salmon trout, Salmo trutta. J. Fish Biol., 1: 169-182. 
Blay, Jr. J. and K.W. Eyeson, 1982. Observations on the reproductive biology of the Shad, Ethmalosa fimbriata (Bowdich) in the coastal waters of Cape coast, Ghana. J. Fish Biol., 21: 485-496.

Brown, C.A., 1991. Community structure and secondary production of benthic macrofauna of Lagos lagoon harbour. M. Phil Thesis, University of Lagos, Nigeria.

Danilenko, T.P., 1983. The reproductive cycle of the pike, Esox lucius, L. in the kanev reservoir. Hydrobiology, 18: $21-27$.

El-Greisy, Z., 2000. Reproductive biology and physiology of Diplodus sargus (Family: Sparidae) in the Mediterranean environment. Ph.D. Thesis, Department of Environmental Studies Institute of Graduste Studies Alex. University.

Etim, L., R.P. King and M.T. Udo, 2002. Breeding, growth, mortality and yield of the mudskipper, Periophthalmus barbarus (Linneaus 1766) (Teleostei: Gobiidae) in the Imo River estuary, Nigeria. Fish. Res., 56: $227-238$.

FAO, 1990. Field Guide to Commercial Marine Resources of the Gulf of Guinea. Food and Agriculture Organization, Rome, Italy, pp: 265

Fagade, S.O. and C.I.O. Olaniyan, 1972. The biology of the West Africa Shad, Ethmalosa fimbriata (Bowdich) in the Lagos lagoon, Nigeria. J. Fish Biol., 4: 519-533.

Fagade, S.O. and C.I.O. Olaniyan, 1973. The food and feeding interrelationships of the fishes in Lagos lagoon, Nigeria. J. Fish Biol., 5: 205-225.

Garcia-Diaz, M., J.A. Gonzalez, M.J. Lorente and V.M. Tuset, 2006. Spawning season, maturity sizes, and fecundity in blactail comber (Serranus atricauda) (Serranidae) from the eastern-central Atlantic. Fish. Bull., 104: 159-166.

Hay, D.E. and B.R. Brett, 1988. Maturation and fecundity of Pacific herring (Clupea harengus pallasii), an experimental study with comparisons to natural populations. Can. J. Fish. Aquat. Sci., 45: 399-406.

Honji, R.M., A.M. vas dos Santos and W.S. Rossi, 2006. Identification of the stages of ovarian maturation of the Argentine hak Merluccius hubbsi, Marini, 1993 (Teleostei: Merlucciidae) advantages and disadvantages of the use of the macroscopic and microscopic scales. Neotrop. Ichthiol, 443: 329-337.

Ip, Y.K., W.P. Low, A.L.L. Lim and S.F. Chew, 1990. Changes in lactate content in the gill of the mudskippers, Periophthalmus chrysospilos and Boleophthalmus boddaerti in response to environmental hypoxia. J. Fish Biol., 36: 481-487.

Irvine, F.R., 1947. The Fishes and Fisheries of Gold Coast. Crown Agent, London, pp: 352.
Jaafar, Z. and H.K. Larson, 2008. A new species of mudskipper, Periophthalmus takita (Teleostei: Gobiidae: Oxudercinae), from Australia, with a key to the genus. Zool. Sci., 25: 946-952.

Jaafar, Z., K.K.P. Lim and L.M. Chou, 2006. Taxonomical and morphological notes on two species of mudskippers, Periophthalmus walailakae and Periophthalmodon schlosseri (Teleostei: Gobiidae) from Singapore. Zool. Sci., 23: 1043-1047.

Jone, A., 1974. Sexual maturity, fecundity and growth of Turbot, Scophthalmus maximum(L.). J. Mar. Biol. Assoc. UK., 54: 109-125.

Khaironizam, M.Z. and Y. Norma-Rashid, 2002. Length-weight relationship of mudskippers (Gobiidae: Oxudercinae) in the coastal areas of Selangor, Malaysia. NAGA-World Fish Centre Q., 25: 20-22.

Kusemiju K., A.A. Oki and M. Graham-Douglas, 1983. On the biology of an estuarine population of the Clupeid, Pellonula afzeliusi in Lagos Lagoon, Nigeria. Hydrobiology, 102: 55-59.

Kusemiju, K., 1976. Distribution, reproduction and growth of catfish, Chrysichthys walkeri (Gunther) in the Lekki lagoon, Nigeria. J. Fish Biol., 8: 453-458.

Lawson, E.O. and A.F Aguda, 2010. Growth patterns, diet composition and reproduction in the ten pounder, Elops lacerta from Ologe lagoon, Lagos, Nigeria. Agric. Biol. J. N. Am., 1: 974-984.

Lawson, E.O., 1991. Biology of the Grey mullet, Mugil cephalus, L. in Lagos lagoon, Nigeria. M.Sc. Thesis, University of Lagos, Nigeria.

Lawson, E.O., 1998. Bio-ecology of the Mudskipper, Periophthalmus papilio in the mangrove swamps of Lagos lagoon, Nigeria. Ph.D. Thesis, University of Lagos, Nigeria.

Lawson, E.O., 2004a. Distribution patterns, age determination and growth studies of Mudskipper, Periophthalmus papilio in mangrove swamps of Lagos lagoon, Lagos, Nigeria. J. Res. Rev. Sci., 3: $293-297$.

Lawson, E.O., 2004b. Food and feeding habits of mudskipper, Periophthalmus papilio in mangrove swamps of Lagos lagoon, Lagos, Nigeria. J. Res. Rev. Sci., 3: 355-358.

Marcus, O., 1982. The biology of the Clupeid, Ilisha africana (Bloch) off the Nigerian coast. Ph.D. Thesis, University of Lagos, Nigeria.

Mohamed, A.E.G.A.A., 2010. The reproductive biology and the histological and ultrastructural characteristics in ovaries of the female gadidae fish Merluccius merluccius from the Egyptian Mediterranean water. Afr. J. Biotechnol., 9: 2544-2559. 
Murdy, E.O., 1989. A Taxonomic Revision and Cladistic Analysis of the Oxudercine Gobies (Gobiidae: Oxudercinae). Australian Museum, Canberra, ACT Australia, pp: 1-93.

Olaniyan, C.I.O., 1957. The seasonal variation in plankton in the Lagos Habour, Nigeria. Ph.D. Thesis, London University.

Oyenekan, J.A., 1972. A survey of the Lagos lagoon benthos with particular reference to molluscs. M.Sc. Thesis, University of Lagos.

Salem, S.B., M.I. Zaki, M.M. El-Gharabawy, I.K. El-Shorbagy and K.F. El-Boray, 1994. Seaonal histological changes in the ovaries of Mugil seheli from Suez Bay. Bull. Nat. Inst. Oceanogr. Fish. ARE., 20: 235-249.

Sarimin, A.S., M.A. Ghaffar and C.A.R. Mohamed, 2009. Variation of $\mathrm{Ca}, \mathrm{Sr}, \mathrm{Ba}$ and $\mathrm{mg}$ in the Otolith of mudskipper in west coast of peninsular Malaysia. Pak. J. Biol. Sci., 12: 231-238.
Swanson, B.O. and C.G. Alice, 2004. Kinematics of aquatic and terrestrial escape responses in mudskippers. J. Exp. Biol., 207: 4037-4044.

Thorpe, J.E., M.S. Miles and D.S. Keay, 1984. Developmental rate, fecundity and egg size in Atlantic salmon, Salmo salar L. Aquaculture, 43: 289-305.

Udo, M.T., 2002. Intersexual plasticity in aspects of the biology of the mudskipper Periophthalmus barbarus (Gobiidae) in the mangrove swamps of IMO Estuary, Nigeria. J. Environ. Sci., 14: 95-101.

Ugwumba, O.A., 1984. The biology of the ten pounder, Elop lacerta (Val.) in the freshwater, estuarine and marine environment. Ph.D. Thesis, University of Lagos, Nigeria.

Yoloye, V., 1976. The ecology of the West African bloody cockle, Anadara (senilis) senilis (L.) Bull. Inst. Francais d'Afrique Noire Dakar, 38: 25-56. 